\title{
Estudio de la cinética de hidratación de cemento con adición
}

\section{Hidration kinetics study of the mixed cements}

\author{
GABRIEL L. DUQUE FERNÁNDEZ \\ Departamento Central del Cemento del MIMC \\ DAVID DÍAZ QUINTANILLA, MANUEL ZAPATA SIERRA, ESTER RUBIO FRÍAS \\ CEADEN, P. O. Box 6122, La Habana
}

Fecha de recepción: 18-VI-93.

CUBA

\section{RESUMEN}

Se hizo un estudio por diferentes métodos de la hidratación de cementos con $10 \%$ y $20 \%$ de adición de una toba del yacimiento "Las Carolinas", en la provincia de Cienfuegos (Cuba). Hubo una buena correspondencia entre las diferentes técnicas de análisis utilizadas, comprobándose que en los cementos mezclados se incrementan los productos de hidratación, se acelera la hidratación de la alita, aumenta el contenido de agua fija, asi como que la resistencia del cemento, con hasta $10 \%$ de adición, es similar al cemento puro para tiempos de curado de 3 y 28 dias, mientras que con $20 \%$ de adición sólo se igualan después de los 180 días.

\author{
$S U M M A R Y$ \\ A study of the hydration process of cements with $10 \%$ and \\ $20 \%$ addition of a tuff from "Las Carolinas" quarry \\ (Cienfuegos, Cuba) by different methods was done. The \\ results obtained by different methods showed a good \\ agreement. It was proved an increment of the hydration \\ products, an acceleration of alite hydration and a swelling \\ of the fixed water in mixed cements. The resistance of the \\ cement with $10 \%$ addition is similar to that of the pure \\ cement for ages of 28 days, whereas with $20 \%$ addition \\ they were similar only after 180 days.
}

\section{INTRODUCCIÓN}

Los cementos con adición brindan la forma más segura y económica de obtener ahorros sustanciales de energía en la industria de materiales de construcción (1), de ahi que sea imprescindible el desarrollo de técnicas de ensayo, así como el continuo estudio de las propiedades de los cementos obtenidos.

El cemento es una mezcla de diferentes fases mineralógicas que se hidratan de manera simultánea, lo que dificulta el estudio del proceso de hidratación. Es por eso que en los cementos mezclados, donde la adición activa entra como una fase adicional, dicha investigación se hace más complicada. En general se recomienda un estudio integral, por diferentes métodos, para alcanzar la comprensión del proceso de hidratación (2).

\section{INTRODUCTION}

The mixed cements are the safest and cheapest way of obtaining remarkable energy savings in the construction materials industry (1), thus it is essential the development of the assay methods as well as a continuous study of the properties of the obtained cements.

The cement is a mixture of different mineralogical phases hydrating simultaneously, thus the study of the hydration process is difficult. That is why in mixed cements, in which the active addition enters as an additional phase, the study becomes more complicated. It is generally recommended an integral study by different methods in hydration process comprehension (2). 


\section{MATERIALES Y MÉTODOS}

Se tomó un cemento de la fábrica "Karl Marx" de la provincia de Cienfuegos, al que se le adicionaron $10 \%$ y $20 \%$ de una toba del yacimiento "Las Carolinas" de la misma provincia. Se prepararon las tres muestras siguientes:

$\mathrm{C}_{1}$ : cemento portland.

$\mathrm{C}_{2}$ : cemento portland $+10 \%$ de toba.

$\mathrm{C}_{3}$ : cemento portland $+20 \%$ de toba.

De los análisis químicos de rutina de la toba, $y$ del cemento que se presentan en las tablas 1 y 2 , se puede decir que éste es un cemento P-350 de alta calidad.

Las mediciones de difracción de rayos X (DRX) (3) utilizadas en la determinación del grado de reacción, del contenido de hidróxido de calcio por termogravimetría y de la determinación del contenido de agua fija (4), requieren detener la reacción por métodos químicos y la realización del ensayo en un periodo muy breve o de lo contrario la muestra se deteriora, por lo que sólo se les realizaron a las muestras $C_{1}$ y $C_{2}$.

Los resultados del grado de reacción fueron divididos en dos grupos. Para el primero, a las edades de 1, 3 y 7 días, se tomó como referencia al cemento anhidro; en el segundo, a las edades de 14, 21 y 28 días, se usó como referencia la muestra hidratada 24 horas.

A todas las muestras se les determinó mediante la técnica de Resonancia Magnética Nuclear (RMN) $(5,6)$ las dependencias temporales del agua no cristalina y de la superficie especifica de los productos de hidratación Zrmn, así como la superficie específica por gramo de cemento Srmn.

Se determinó la resistencia de los morteros según la norma cubana (7).

Se midió también el pH de la solución sobrenadante hasta 1 año.

\section{RESULTADOS Y DISCUSIÓN}

El grado de reacción de la alita en el primer grupo se muestra en la tabla 3, donde se observa una aceleración de la misma al primer día, un retardo a los 3 días y una posterior aceleración a los 7 días; en el segundo grupo que se muestra en la tabla 4 se observa una aceleración a todas las edades. Esto es explicable teniendo en cuenta que en presencia de acomplejantes del calcio

\section{EXPERIMENTAL PROCEDURE}

A tuff from "Las Carolinas" quarry (province of Cienfuegos, Cuba) was added to a cement from the factory "Karl Marx" (at the same province), thus obtaining the following samples:

$$
\begin{aligned}
& C_{1}: \text { Cement portland. } \\
& C_{2} \text { : Cement portland }+10 \% \text { tuff. } \\
& C_{3} \text { : cement portland }+20 \% \text { tuff. }
\end{aligned}
$$

The routine chemical analysis for the cement and the tuff are shown in tables 1 and 2. It may be said that the cement is a high quality P-350.

The determination of the reaction grade by $X$-Ray diffraction, the analysis of $\mathrm{Ca}(\mathrm{OH})_{2}$ by thermogravimetry and the determination of the fixed water content (4), must be intermupted by chemical methods and the fulfillment of the assay must be done in a very short time. Otherwise, the sample deteriorates. Because of the reasons above, those analysis were made in samples $C_{1}$ and $C_{2}$ only.

The results for the reaction grade were divided into 2 groups. In the first, for ages of 1, 3 and 7 days the anhydrous cement was taken as reference. In the second, for ages of 14, 21 and 28 days the sample with 24 hours hydration was used as reference.

In all samples, the time dependence of the non-crystalline water, the specific surface of the hydration products (Znmr) and the specific surface per gram of cement (Snmr) was determined by using the Nuclear Magnetic Resonance (NMR) $(5,6)$.

The resistance of the mortars was determined as described in the Cuban Standard (7).

The $\mathrm{pH}$ of the overflowing solution until 1 year was also measured.

\section{RESULTS AND DISCUSSION}

The alite reaction grade in the first gruop is shown in table 3. An acceleration of the reaction during the first day, a retardation three days later and a latter acceleration at the seventh day are observed. In the second group, as shown in table 4 , an acceleration at all ages is observed. The above may be explained considering that in presence of Ca complexing agents as EDTA, an 
TABLA 1 TABLE 1

Análisis químico de cemento

(Chemical analysis of the cement)

\begin{tabular}{|l|c|}
\hline \multicolumn{1}{|c|}{$\begin{array}{c}\text { Composición } \\
\text { (Composition) }\end{array}$} & $\begin{array}{c}\text { \% en peso } \\
\text { (\% in veight) }\end{array}$ \\
\hline $\mathrm{SiO}_{2}$ & 21,6 \\
\hline $\mathrm{Al}_{2} \mathrm{O}_{3}$ & 2,5 \\
\hline $\mathrm{Fe}_{2} \mathrm{O}_{3}$ & 6,3 \\
\hline $\mathrm{CaO}$ & 63,2 \\
\hline $\mathrm{MgO}$ & 1,7 \\
\hline $\mathrm{Na}_{2} \mathrm{O}$ & 0,27 \\
\hline $\mathrm{K}_{2} \mathrm{O}$ & 0,28 \\
\hline $\mathrm{SO}{ }_{3}$ & 2,54 \\
\hline $\mathrm{Cal}$ libre (free lime) & 1,21 \\
\hline $\mathrm{R} . \mathrm{I}$. & 1,07 \\
\hline $\mathrm{P} . \mathrm{F}$. & 1,7 \\
\hline $\mathrm{C}_{3} \mathrm{~S}$ & 56,6 \\
\hline $\mathrm{C}_{2} \mathrm{~S}$ & 19,1 \\
\hline $\mathrm{SSFF}$ & \\
\hline
\end{tabular}

TABLA 2 TABLE 2

Análisis químico de la toba (Chemical analysis of the tuff)

\begin{tabular}{|l|c|}
\hline $\begin{array}{c}\text { Composición } \\
\text { (Composition) }\end{array}$ & $\begin{array}{c}\text { \% en peso } \\
\text { (\% in veight) }\end{array}$ \\
\hline $\mathrm{SiO}_{2}$ & 58,7 \\
\hline $\mathrm{Al}_{2} \mathrm{O}_{3}$ & 14,1 \\
\hline $\mathrm{Fe}_{2} \mathrm{O}_{3}$ & 5,9 \\
\hline $\mathrm{CaO}$ & 4,8 \\
\hline $\mathrm{MgO}$ & 2,3 \\
\hline $\mathrm{Na} O$ & 1,55 \\
\hline $\mathrm{K}_{2} \mathrm{O}$ & 1,7 \\
\hline
\end{tabular}

TABLA 3 TABLE 3

Grado de reacción para $\mathrm{C}_{1}$ y $\mathrm{C}_{2}$ a los 1, 3 y 7 días

(Reaction grade for $C_{1}$ and $C_{2}$ in 1, 3 and 7 days)

\begin{tabular}{|c|c|c|c|}
\hline $\begin{array}{c}\text { Muestra } \\
\text { (Sample) }\end{array}$ & $\begin{array}{c}\mathbf{1} \text { día } \\
\text { (1 day) }\end{array}$ & $\begin{array}{c}3 \text { días } \\
\text { (3 days) }\end{array}$ & $\begin{array}{c}7 \text { días } \\
\text { (7 days) }\end{array}$ \\
\hline$C_{1}$ & 0,18 & 0,32 & 0,36 \\
\hline$C_{2}$ & 0,24 & 0,29 & 0,46 \\
\hline
\end{tabular}

TABLA 4 TABLE 4

Grado de reacción para $\mathrm{C}_{1}$ y $\mathrm{C}_{2}$ a los 14,21 y 28 días

(Reaction grade for $C_{1}$ and $C_{2}$ in 14, 21 and 28 days)

\begin{tabular}{|c|c|c|c|}
\hline $\begin{array}{c}\text { Muestra } \\
\text { (Sample) }\end{array}$ & $\begin{array}{c}\mathbf{1 4} \text { días } \\
\text { (14 days) }\end{array}$ & $\begin{array}{c}\mathbf{2 1} \text { días } \\
\text { (21 days) }\end{array}$ & $\begin{array}{c}\mathbf{2 8} \text { días } \\
\text { (28 days) }\end{array}$ \\
\hline $\mathrm{C}_{1}$ & 0,31 & 0,42 & 0,54 \\
\hline $\mathrm{C}_{2}$ & 0,33 & 0,45 & 0,61 \\
\hline
\end{tabular}

TABLA 5 TABLE 5

Contenido $(\%)$ de $\mathrm{Ca}(\mathrm{OH})_{2}$ por termogravimetria [Ca(OH) $)_{2}$ content (\%) (Thermogravimetry)]

\begin{tabular}{|c|c|c|c|c|}
\hline $\begin{array}{c}\text { Mues- } \\
\text { tra } \\
\text { (Sam- } \\
\text { ples) }\end{array}$ & $\begin{array}{c}\mathbf{7} \\
\text { días } \\
\mathbf{( 7} \\
\text { days) }\end{array}$ & $\begin{array}{c}\mathbf{1 4} \\
\text { días } \\
\mathbf{( 1 4} \\
\text { days) }\end{array}$ & $\begin{array}{c}\mathbf{2 1} \\
\text { días } \\
\mathbf{( 2 1} \\
\text { days) }\end{array}$ & $\begin{array}{c}\mathbf{2 8} \\
\text { días } \\
\mathbf{2 8} \\
\text { days) }\end{array}$ \\
\hline$C_{1}$ & 13,9 & 14,7 & 15,2 & 16,1 \\
\hline$C_{2}$ & 12,5 & 13,0 & 12,8 & 12,6 \\
\hline
\end{tabular}

TABLA 6 TABLE 6

Contenido (\%) de agua fija [Fixed water content (\%)]

\begin{tabular}{|c|c|c|c|c|}
\hline $\begin{array}{c}\text { Mues- } \\
\text { tra } \\
\text { (Sam- } \\
\text { ples) }\end{array}$ & $\begin{array}{c}\mathbf{7} \\
\text { días } \\
\mathbf{( 7} \\
\text { days) }\end{array}$ & $\begin{array}{c}\mathbf{1 4} \\
\text { dias } \\
\mathbf{( 1 4} \\
\text { days) }\end{array}$ & $\begin{array}{c}\mathbf{2 1} \\
\text { días } \\
\mathbf{( 2 1} \\
\text { days) }\end{array}$ & $\begin{array}{c}\mathbf{2 8} \\
\text { días } \\
\mathbf{2 8} \\
\text { days) }\end{array}$ \\
\hline $\mathrm{C}_{1}$ & 11,5 & 12,0 & 12,1 & 13,1 \\
\hline $\mathrm{C}_{2}$ & 12,6 & 13,4 & 14,0 & 14,6 \\
\hline
\end{tabular}


como el EDTA, según (8), se observa un período de aceleración de la reacción en los primeros momentos con un retardo posterior. En un trabajo anterior se demuestra que la toba utilizada se comporta prácticamente como un acomplejante del calcio (9). La aceleración después de los tres días se debe al inicio de la reacción puzolánica propiamente dicha.

En los resultados termogravimétricos presentados en la tabla 5 , se observa una disminución sustancial del contenido de $\mathrm{Ca}(\mathrm{OH})_{2}$ en $\mathrm{C}_{2}$, lo que implica la fijación de no menos de $18,9 \mathrm{mg}$ de óxido de calcio por gramo de toba, por lo que se puede afirmar que la misma es un material muy activo (9).

En la tabla 6 se ve, como era de suponer, que el contenido de agua fija es mayor en los cementos con adición, así como que a partir de los 14 días éste se va incrementando. Esto también se observa en las mediciones por RMN de la dependencia temporal de la cantidad de agua no cristalina representada en la Fig. 1, donde se observa una disminución de la misma.

En la Fig. 2 podemos ver la cinética del desarrollo superficial de los productos de hidratación. Al principio de la hidratación, como es de suponer, la superficie de los hidratos es similar y relativamente pequeña para las tres muestras, con valores de $25 \mathrm{~m}^{2} / \mathrm{g}, 47 \mathrm{~m}^{2} / \mathrm{g}$ y $55 \mathrm{~m}^{2} / \mathrm{g}$ para $\mathrm{C}_{1}, \mathrm{C}_{2}$ y $\mathrm{C}_{3}$ respectivamente. A partir del quinto día se observa una disminución de la velocidad de formación de nuevos productos hidratados. Los valores promedio de Zrmn para $\mathrm{C}_{1}, \mathrm{C}_{2}$ y $\mathrm{C}_{3}$ son $1.700 \mathrm{~m}^{2} / \mathrm{g}, 2.200 \mathrm{~m}^{2} / \mathrm{g}$ y $3.100 \mathrm{~m}^{2} / \mathrm{g}$. Pero después de pasados los primeros 14 días, comienza una violenta reacción del silicato bicálcico en el cemento sin adición. En los cementos con adición el incremento de la superficie de los hidratos es mayor, por lo que puede pensarse en que este proceso está acompañado por la formación de geles de $\mathrm{CSH}$, debido a la reacción entre la cal libre y la toba, de tal modo que se obtienen a los 28 días valores muy altos de Zrmn: $C_{1}-5.093 \mathrm{~m}^{2} / \mathrm{g}, C_{2}$ y $\mathrm{C}_{3}-7.640 \mathrm{~m}^{2} / \mathrm{g}$. Lo anterior demuestra una vez más la actividad de la toba.

Las superficies específicas por gramo de cemento Srmn iniciales fueron para $\mathrm{C}_{1}, \mathrm{C}_{2}$ y $\mathrm{C}_{3} 10 \mathrm{~m}^{2} / \mathrm{g}$, $20 \mathrm{~m}^{2} / \mathrm{g}$ y $30 \mathrm{~m}^{2} / \mathrm{g}$ respectivamente. En este resultado influye claramente la porosidad propia de la puzolana.

Al estudiar el desarrollo de la resistencia presentado en la figura 3 , se observa que $\mathrm{C}_{2}$ y $\mathrm{C}_{3}$ experimentan incrementos considerables de resistencia a partir de los 7 dias, lo cual puede acceleration of reaction during the first moments and a latter retardation is observed (8). In a previous work it is proved that the used tuff behaves almost as a Ca complexing agent (9). The acceleration after the third day is due to the puzzolanic reaction itself.

In the gravimetric results a remarkable decrease in the $\mathrm{Ca}(\mathrm{OH})_{2}$ content in $\mathrm{C}_{2}$ is observed (see table 5), thus implying the fixation of not less than $18.9 \mathrm{mg}$ of $\mathrm{CaO}$ per gram of tuff. Therefore it can be said that the tuff is a very active material.

In table 6 it is seeen, as supposed, that the fixed water content as well as the increase of that content from the $14^{\text {th }}$ day on are greater in the cements with addition. The above is also seen in the decreasing time dependence of the non-crystalline water amount (see fig. 1) found by NMR measurements.

Fig. 2 shows the kinetics of the hydration products surface development. At the beginning of the hydration, as supposed, the hydrates surface is similar and relatively low in the three samples: $25 \mathrm{~m}^{2} / \mathrm{g}$ for $C_{1}, 47 \mathrm{~m}^{2} / \mathrm{g}$ for $C_{2}$ and $55 \mathrm{~m}^{2} / \mathrm{g}$ for $\mathrm{Ca}$. From the fifth day on, a reduction in the new hydration products formation grade occurs. The mean values of $\mathrm{Znmr}$ for $C_{1}, C_{2}$ and $C_{3}$ are $1700 \mathrm{~m}^{2} / \mathrm{g}, 2200 \mathrm{~m}^{2} / \mathrm{g}$ and $3100 \mathrm{~m}^{2} / \mathrm{g}$. But after the first 14 days, a violent reaction of bicalcic silicate in the pure cement begins. In the cements with additions, the increment of the hydrates surface is greater and suggest that this process is accompanied by the formation of $\mathrm{CSH}$ gels due to the reaction of the free lime and the tuff. After 28 days, very high values of $\mathrm{Znmr}$ are obtained: $C_{1}-5093 \mathrm{~m}^{2} / \mathrm{g}, C_{2}$ and $C_{3}-7640 \mathrm{~m}^{2} / \mathrm{g}$. That proves once more the activity of the tuff.

The initial values of the specific surface per gram of cement Snmr were $10 \mathrm{~m}^{2} / \mathrm{g}, 20 \mathrm{~m}^{2} / \mathrm{g}$ and $30 \mathrm{~m}^{2} / g$ for $C_{1}, C_{2}$ and $C_{3}$ respectively. The porosity characteristic of the puzzolana clearly influences on those results.

When studying the resistance development shown in fig. 3 it is found that $C_{2}$ and $C_{3}$ present considerable increments of resistance from the seventh day on which may be attributed to the 


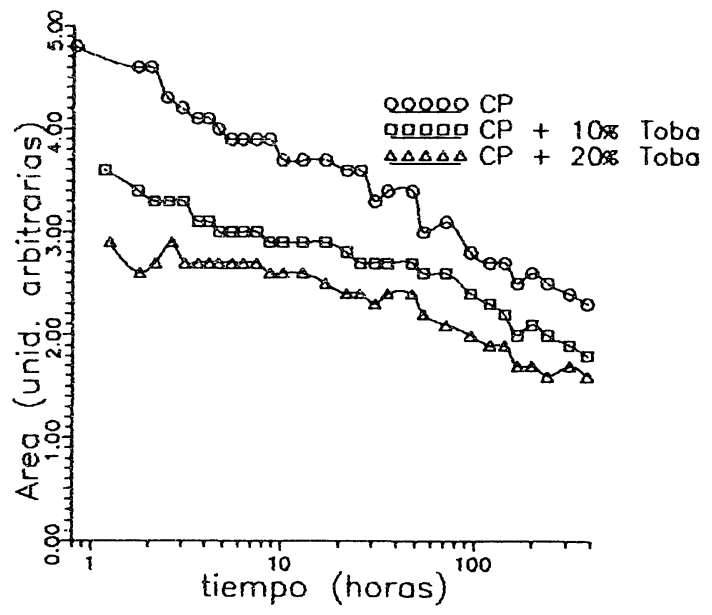

Fig. 1.-Dependencia temporal de la cantidad de agua no cristalina.

Fig. 1.-Temporal dependence of non-crystalline water amount.

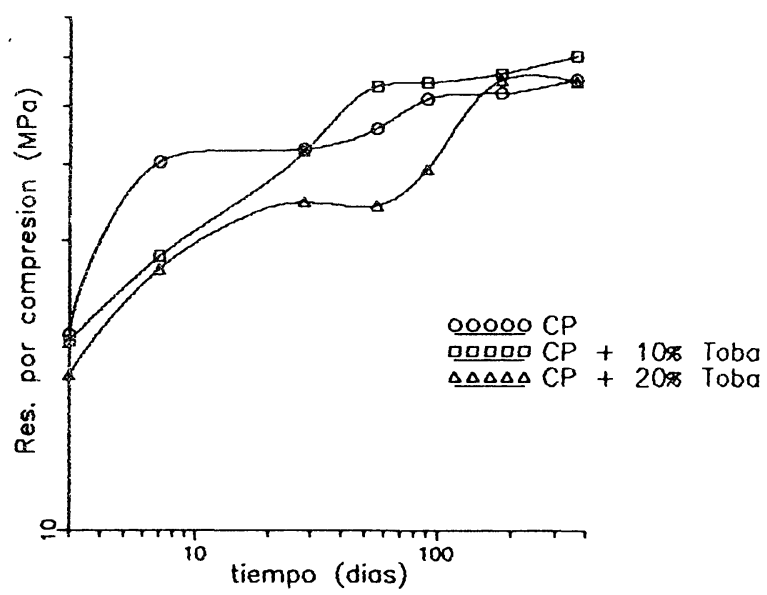

atribuirse a la adición. $\mathrm{A}$ los 180 días se observa que el cemento $\mathrm{C}_{3}$ alcanza la resistencia atribuible a un cemento con $20 \%$ de adición de inerte, y a partir de esta edad alcanza valores comparables a $\mathrm{C}_{1}$.

En las mediciones del $\mathrm{pH}$ realizadas hasta un año, éste se mantuvo en todos los casos por encima de 12, por lo que existe la protección química requerida para las armaduras metálicas.

\section{CONCLUSIONES}

Los cementos con adiciones fijan mayor cantidad de agua, desarrollan una mayor superficie específica de los productos de hidratación, y alcanzan resistencias comparables al cemento sin adición a edades de $\mathbf{2 8}$ días en el cemento con $10 \%$ de adición y a los 180 días en el de $20 \%$.

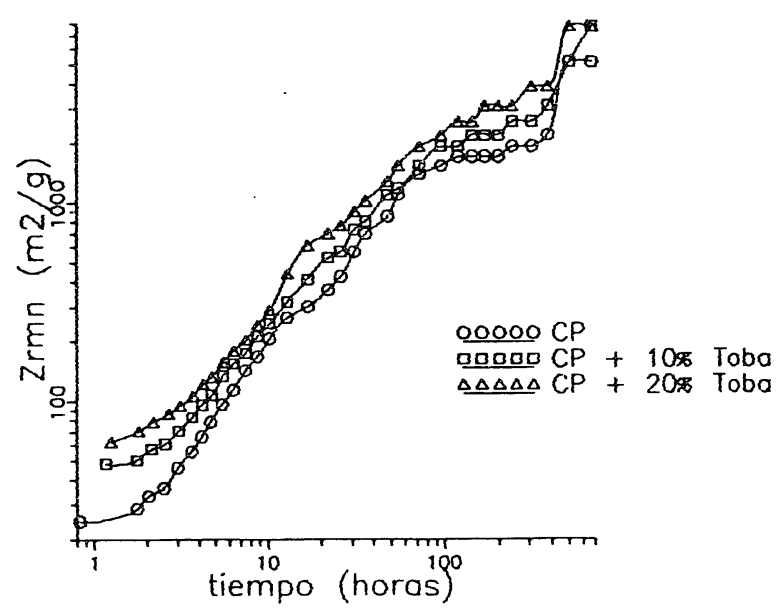

Fig. 2.-Dependencia temporal de la superficie específica de los productos de hidratación Zrmn.

Fig. 2.-Temporal dependence of the hydration products specific surface.

Fig. 3.-Dependencia temporal de la resistencia por compresión.

Fig. 3.-Temporal dependence of compressive strength.

addition. Up to 180 days the cement $C_{3}$ acquires the resistance proper of a cement with an addition of $20 \%$ of inert, and only from that age on the values are similar to those in $C_{1}$.

The $\mathrm{pH}$ was studied during a year, and it was always found over 12 thus, the required chemical protection for the iron grid exist.

\section{CONCLUSIONS}

The cements with addition fix a greater amount of water and develop a larger specific surface of the hydration products. At ages of 28 days in the cement with $10 \%$ addition and 180 days in the one with $20 \%$ addition they reach resistance similar to that of the cement without addition. 
(1) HERRERO NÚÑEZ: Curso de ahorro de energía en el sector del cemento MIMC, p. 32-61, 1990.

(2) DENT GLASSER, L. S. et al.: Cem. Conc. Res. v. 8, n. 6, p. 733-739. 1978.

(3) DUQUE G.; LLÓPIZ, J. C.; RUBIO, E.: Materiales de Construcción, v. 39, n.ำ 213, p. 5-10, 1989.

(4) DUQUE, G.; VELÁZQUEZ, J.: Ingeniería Estructural y Vial. v. 2, p. 15-19, 1989.

(5) BARBIČ, et al.: Am. Ceram. Soc. v. 65, n. 1, p. 25-31. 1982.

(6) DÍAZ, D. et al.: Estudio de la cinética del fraguado de cementos P-350 por Resonancia Magnética Nuclear (en preparación).

(7) Norma Cubana 54.207:80. Materiales y Productos de la construcción. Cemento. Ensayos físico-mecánicos. 1980.

(8) TOMAS, N. L.; DOUBLE, D. D.: Cem. Concr. Res. v. 13, n.ํ 3, p. 391-400. 1983.

(9) DUQUE, G. L. et al.: Memorias del Congreso Internacional de la Construcción, mayo 1992. Montreal, Canadá.

\section{publicación del ICCET/CSIC}

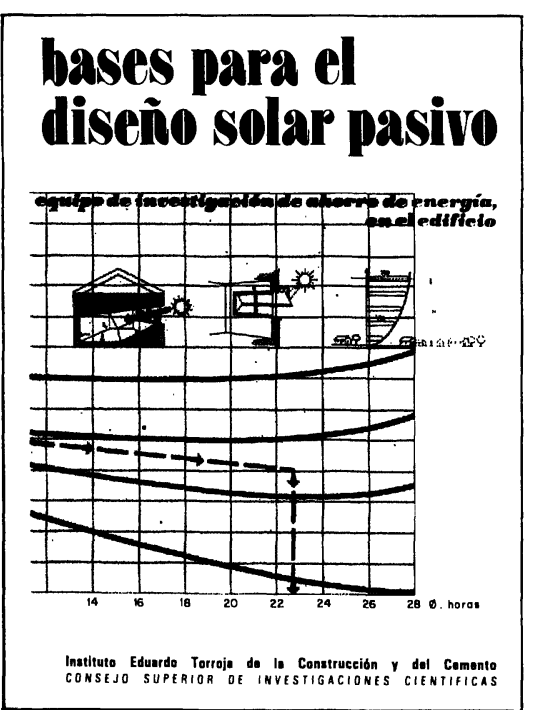

22
Equipo de Ahorro de Energía en el edificio

Arturo Garcia Arroyo

M. a José Escorihuela

José Luis Esteban

José Miguel Frutos

Manuel Olaya

Bernardo Torroja
Dirección y coordinación:

Las dificultades de suministro y el alto coste de los productos energéticos convencionales han despertado la atención de los usuarios técnicos e industriales de la edificación hacia los procedimientos y sistemas en que se basa el aprovechamiento de otras fuentes alterna tivas de energia, principalmente la solar. Esto ha generado un rápido desarrollo industrial y comercial que, en opinión de los autores de comercial que,

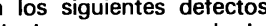
un mimético tecnologismo respecto de los sistemas convencionales que violenta las pe culiaridades de la energia solar (baja densidad y variabilidad en el tiempo), y una escasa selectividad en la aplicación de los sistemas y procedimientos pasivos dando origen a un ecumenismo arquitectónico solar, al margen de las condiciones climáticas y funcionales específicas de cada caso y lugar.

En este libro, utilizando criterios y metodologia pedagógicos, se dan los fundamentos e instrumentos teórico-prácticos necesarios para el planteamiento de todo proyecto arquitectónico solar pasivo, de acuerdo con los principios éticos y económicos de conservación y ahorro de energia. Es decir: respeto de los presupuestos bioclimáticos, búsqueda de la máxima captación y acumulación de la radiación solar, y esmero en el aislamiento térmico de los cerramientos.

Un volumen encuadernado en cartulina ibiza plastificada, a cinco colores, de $16 \times 23 \mathrm{~cm}$, compuesto de 216 páginas, 217 figuras, 87 gráficos, 19 tablas y 10 cuadros. 